\title{
STRATEGY FOR DEVELOPING THE FERTILIZER SECTOR IN BANGLADESH FOR SUSTAINABLE AGRICULTURE
}

\author{
A. K. M. Abdul Quader* \\ Department of Chemical Engineering, Bangladesh University of Engineering and Technology (BUET), Dhaka-1000
}

Received 28 October 2009; received in revised form 20 December 2009

\begin{abstract}
A strategic program for developing the fertilizer sector in Bangladesh for sustainable agriculture is presented in this paper. Based on the land utilization and likely cropping patterns in the future, the expected demands for different fertilizers such as urea, diammonium phosphate, TSP, SSP and MOP have been estimated. Considering the production capacities of different fertilizers in the country as well as the conditions of the plants against the estimated demands, Bangladesh immediately requires to add additional production capacities for urea (1122,000 tpy), SSP (960,000 tpy), Phosphoric acid (226,000 tpy, $\left.100 \% \mathrm{P}_{2} \mathrm{O}_{5}\right)$, Sulfuric Acid (1000,000 tpy) and Muriate of Potash (700,000 tpy). The estimated investment for adding these capacities would be around US\$ 1860 million. If these additional capacities are not built, the costs for import of different fertilizers including staple cereals would be in excess of US\$ 1700 (fertilizer $\approx$ US\$ 900) million every year. If the envisaged projects for adding capacities are implemented, this will make the agriculture sustainable and less dependent on import of fertilizers.
\end{abstract}

Keywords: Urea, TSP, DAP, Development strategy

DOI:10.3329/cerb.v13i2.3126

\section{Introduction}

The consumption of chemical fertilizer in Bangladesh since its introduction in 1951-52 has steadily increased as the country has been modernizing its agriculture for attaining autarky in food grain production thereby ensuring food security and improving nutritional status $[1,2]$. The total food grain production (rice, wheat and maize) rose from 19.06 million ton in 1995-96 to 28.88 million ton in 2005-2006. Now there is hardly any crop that does not use fertilizer. The major chemical fertilizers used are: Urea, TSP (Triple Super Phosphate), SSP ( Single Super Phosphate), DAP (Diammonium Phosphate), MP (Muriate of Potash), Ammonium Sulfate (AS), Zinc Sulfate, Gypsum, NPKS (Nitrogen-PhosphorousPotassium-Sulfur containing mixture) etc. The total consumption of these fertilizers increased from 3.023 million ton in 1995-96 to 3.683 million ton in 2005-06. Urea constitutes about 67 percent of all the fertilizers consumed in 2005-06; while Zinc Sulfate and Gypsum are micro-nutrients and they constitute only 3.07 percent of the total fertilizer consumption.

The natural Gas Fertilizer Factory (NGFF at Fenchugonj) which was commissioned in 1961 was the first Urea fertilizer complex in the country based on indigenous natural gas as feedstock and fuel. Thereafter, six more natural gas based urea fertilizer complex have come on-stream. The commercial production of TSP begun in 1973 at TSP Complex in Chittagong with imported raw materials (Sulfur and Phosphate Rock). Bangladesh does not have any potash fertilizer production facility. Gypsum is a by-product of TSP complex while producing Phosphoric Acid. Zinc sulfate is produced by small operators using waste zinc as raw material. The commercial production of ammonium sulfate begun in 1969 and it is specifically used in tea plants.

The agriculture is still an important segment of the country's economy though the contribution of broad agriculture sector in 2005-06 to GDP was $21.84 \%$. Crops and vegetables accounted for about $12 \%$ of GDP [3]. About 52 percent of the total labor forces of the country are engaged in agriculture [3]. To feed the growing population of Bangladesh (at the rate 1.59\% per year) increased agriculture production especially staple cereal rice is a must. In the year 2006-07, the staple cereal rice was grown in 11.30 million hectare. HYV (High Yield Variety) rice was produced on 8.50 million hectare. Of the total cropped area of 14.11 million hectare in 2004-05, the net cropped area was 7.98 million hectare giving a cropping intensity of 1.77 [1, 4]. The Department of Agriculture Extension (DAE) claims that the current cropping intensity is $195 \%$.

*Corresponding author Email: quader@che.buet.ac.bd 


\section{Estimation of the Demand of Fertilizers}

In the context of Bangladesh, not all cultivable land is suitable for growing rice or wheat; and it is also not practical to produce only cereals. It is reasonable to assume that in near future the predominant variety of rice will be HYV type and all the local varieties except the exotic ones will be replaced with HYV. The same will take place with other crops including vegetables and fruits. Table 1 lists net land area under cultivation, total cropped area and cropping intensity for 2000-01 to 2005-06.

Table 1: Trends of Cropping Intensity in Bangladesh (area in million hectare)[1]

\begin{tabular}{lcccc}
\hline Year & Total land & Net cropped & Total cropped & Cropping intensity $(\%)$ \\
\hline $2000-01$ & 14.85 & 8.08 & 14.3 & 176.9 \\
$2001-02$ & 14.85 & 8.03 & 14.2 & 176.8 \\
$2002-03$ & 14.85 & 8.03 & 14.22 & 177.1 \\
$2003-04$ & 14.85 & 8.03 & 14.22 & 177.1 \\
$2004-05$ & 14.85 & 7.98 & 14.11 & 176.8 \\
$2005-06$ & 14.85 & 7.98 & 14.11 & 176.8 \\
\hline
\end{tabular}

The cropping intensity for 2000-2006 was close to $177 \%$. Table 2 lists land area under cultivation for cereals such as rice and wheat.

Table 2: Land Utilization for Rice and Wheat (area in thousand hectare)[1]

\begin{tabular}{|c|c|c|c|c|c|c|c|c|}
\hline \multirow[t]{2}{*}{ Crops } & & & \multicolumn{6}{|l|}{ Year } \\
\hline & & & $00-01$ & 01-02 & $02-03$ & 03-04 & 04-05 & 05-06 \\
\hline \multirow[t]{9}{*}{ Rice } & Local & Aus & 860 & 792 & 777 & 751 & 574 & 518 \\
\hline & & Amon & 2915 & 2784 & 2475 & 2693 & 2375 & 2236 \\
\hline & & Boro & 202 & 202 & 178 & 208 & 188 & 174 \\
\hline & & Total & 3977 & 3778 & 3700 & 3652 & 3137 & 2928 \\
\hline & HYV & Aus & 466 & 450 & 467 & 452 & 451 & 517 \\
\hline & & Amon & 2798 & 2866 & 2940 & 2987 & 2907 & 3195 \\
\hline & & Boro & 3562 & 3570 & 3668 & 3737 & 3878 & 3894 \\
\hline & & Total & 6828 & 6886 & 7075 & 7176 & 7236 & 7606 \\
\hline & Total & & 10803 & 10664 & 10775 & 10828 & 10373 & 10534 \\
\hline Wheat & & & 773 & 742 & 707 & 642 & 559 & 479 \\
\hline Maize & & & 5 & 20 & 29 & 50 & 67 & 98 \\
\hline
\end{tabular}

It is evident from Table 2 that the cropped area under rice is now about 10.50 million hectare with cropping intensity of $177 \%$. DAE projects that cropping intensity will be around $200 \%$ soon. With cropping intensity of $200 \%$, the cropped rice area would be 11.86 million hectare. It is reasonable to state that ultimately the predominant variety of rice will be HYV type, while the remaining cropped area will be used for other crops but more intensively.

To continue agricultural production at higher levels, one of the important inputs required is the supply of balanced fertilizers consisting of N-P-K besides seeds, irrigation, pesticide, mechanization and bank loan etc. The recommended dose and actual use of urea, TSP and MP for production of HYV type paddy are provided in Table 3.

Table 3 reveals that actual use of all the different fertilizers are below the recommended dose for rice. The same would be true for other crops also. Nonavailability of fertilizers and costs (especially for TSP
Table 3: Recommended Dose and Use of Fertilizers for Difficult HYV Paddy [1]

\begin{tabular}{l|ccc|ccc}
\hline \multirow{2}{*}{ Paddy (HYV) } & \multicolumn{2}{|c|}{$\begin{array}{c}\text { Recommended Dose } \\
\text { (kg/ha)/Actual use(kg/ha) }\end{array}$} & \multicolumn{3}{c}{ Use Gap(\%) } \\
\cline { 2 - 7 } & Urea & TSP & MP & Urea & TSP & MP \\
\hline T.Aus & $141 / 135$ & $101 / 28$ & $69 / 17$ & 4.26 & 72.28 & 75.36 \\
T.Aman & $166 / 135$ & $101 / 30$ & $69 / 24$ & 18.67 & 70.3 & 65.22 \\
Boro & $269 / 192$ & $131 / 47$ & $121 / 37$ & 28.62 & 64.12 & 69.42 \\
\hline
\end{tabular}

and MP) has led to lower use of fertilizers against the recommended dose.

The recommended doses of urea, TSP and MP for production of other crops are provided in Table 4.

Table 4: Recommended Dose of Different Fertilizers for Other Crops [4]

\begin{tabular}{llrrr}
\hline \multirow{2}{*}{ Crops } & \multicolumn{3}{c}{$\begin{array}{c}\text { Recommended Dose } \\
\text { kg/ha }\end{array}$} \\
\cline { 3 - 5 } & & Urea & TSP & MP \\
\hline Paddy (Local) & & & \\
& 1. Broadcast Aus & 104 & 104 & 40 \\
& 2. Broadcast Aman & 77 & 77 & 37 \\
& 3. Boro & 104 & 104 & 40 \\
\hline Wheat & 242 & 47 & 35 \\
\hline Jute & 104 & 25 & 35 \\
\hline Pulses (average) & 52 & 126 & 47 \\
\hline Potato & 277 & 185 & 277 \\
\hline Sugarcane & 277 & 277 & 185 \\
\hline
\end{tabular}

Per hectare yield of HYV and non-HYV type of paddy varies significantly, Table 5. Over the years more acreage has been brought under HYV cultivation, Table 2.

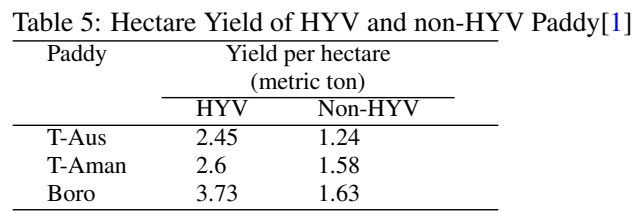

The demand and utilization of chemical fertilizers in the country for the year 2004-05 to 2006-07 are shown in Table 6 .

Table 6: Demand and Utilization of Different Fertilizers (in million metric tons) for years 2004-2008[1]

\begin{tabular}{lcccc|ccc}
\hline \multirow{2}{*}{ Fertilizer } & \multicolumn{2}{l|}{ Demand } & & & \multicolumn{3}{|c}{ Utilization } \\
\cline { 2 - 8 } & $04-05$ & $05-06$ & $06-07$ & $07-08$ & $04-05$ & $05-06$ & $06-07$ \\
\hline Urea & 2.6 & 2.8 & 2.895 & 2.818 & 2.523 & 2.461 & 2.515 \\
TSP & 0.5 & 0.45 & 0.4 & 0.476 & 0.42 & 0.436 & 0.34 \\
SSP & 0.125 & 0.125 & 0.125 & 0.128 & 0.141 & 0.145 & 0.122 \\
DAP & 0.3 & 0.175 & 0.25 & 0.25 & 0.171 & 0.13 & 0.115 \\
MP & 0.45 & 0.3 & 0.3 & 0.4 & 0.26 & 0.291 & 0.23 \\
NPKS & 0.1 & 0.15 & 0.175 & 0.1 & 0.09 & 0.11 & 0.072 \\
Gypsum & 0.15 & 0.15 & 0.15 & 0.16 & 0.136 & 0.105 & 0.072 \\
Zinc Sulfate & 0.025 & 0.25 & 0.03 & 0.045 & 0.008 & 0.008 & 0.026 \\
\hline Total & 4.25 & 4.175 & 4.355 & 4.377 & 3.749 & 3.676 & 3.545 \\
\hline
\end{tabular}

The available data and realities indicate the following cultivation pattern and land utilization for various crops from now onwards.

On the basis of recommended dose of fertilizers for different crops (Tables 3 and 4) and cropping pattern mentioned here above, an estimate of the requirement 
Table 7: Cultivation patterns and estimation of different fertilizers in Bangladesh

\begin{tabular}{|c|c|c|c|c|c|c|c|}
\hline \multirow[t]{2}{*}{ Crop } & \multirow[t]{2}{*}{ Type } & \multirow[t]{2}{*}{$\begin{array}{l}\text { Cropped area } \\
\text { (million ha) }\end{array}$} & \multirow[t]{2}{*}{$\begin{array}{l}\text { Intensity of } \\
\text { cultivation }\end{array}$} & \multirow[t]{2}{*}{ Remarks } & \multicolumn{3}{|c|}{$\begin{array}{c}\text { Estimation of Fertilizer } \\
\text { Requirements in million tons }\end{array}$} \\
\hline & & & & & Urea & TSP & MP \\
\hline Rice & all HYV & 12 & $200 \%$ & $\begin{array}{l}\text { Exotic varieties will be } \\
\text { grown in small areas }\end{array}$ & 2.442 & 1.35 & 1.068 \\
\hline $\begin{array}{l}\text { Jute } \\
\text { Wheat } \\
\text { Sugarcane } \\
\text { Pulse } \\
\text { Potato } \\
\text { Oilseeds etc. }\end{array}$ & all HYV & 1.71 & $\begin{array}{l}\text { Except } \\
\text { sugarcane, } \\
\text { other } \\
\text { more } \\
\text { than } 100 \%\end{array}$ & $\begin{array}{l}\text { Sugarcane-annual crop } \\
\text { Wheat-winter crop } \\
\text { Jute-selective land } \\
\text { Oilseeds-seasonal } \\
\text { Potato-seasonal, selective land } \\
\text { Pulse-seasonal ,selective land }\end{array}$ & 0.3104 & 0.1799 & 0.1672 \\
\hline $\begin{array}{l}\text { Other crops } \\
\text { including } \\
\text { vegetables } \\
\text { and fruits }\end{array}$ & $\begin{array}{l}\text { mostly } \\
\text { HYV }\end{array}$ & 2 & more than $100 \%$ & seasonal and some are cyclic & 0.3 & 0.15 & 0.14 \\
\hline Total & & 15.71 & & & 3.10 & 1.68 & 1.38 \\
\hline
\end{tabular}

of different fertilizers in terms of urea, TSP and MP is presented in Table 7.

Table 7 reveals that the country's requirement of plant nutrients for crops in terms of $\mathrm{N}, \mathrm{P}_{2} \mathrm{O}_{5}$ and $\mathrm{K}_{2} \mathrm{O}$ are $1.426,0.739$ and 0.938 million tons respectively. Table 8 provides nutrient contents of the fertilizers now used in Bangladesh.

Table 8: Fertilizers and Nutrient Content [5]

\begin{tabular}{|c|c|c|}
\hline Fertilizer & Abbreviation & Nutrient Content \\
\hline Urea & - & $45-46 \% \mathrm{~N}$ \\
\hline Ammonium Sulfate & AS & $21 \% \mathrm{~N}$ \\
\hline Diammonium Phosphate & DAP & $18 \% \mathrm{~N}$ and $46 \% \mathrm{P}_{2} \mathrm{O}_{5}$ \\
\hline Muriate of Potash & MP/MOP & $60-62 \% \mathrm{~K}_{2} \mathrm{O}$ \\
\hline Triple Super Phosphate & TSP & $44-48 \% \mathrm{P}_{2} \mathrm{O}_{5}$ \\
\hline Single Super Phosphate & SSP & $16-22 \% \mathrm{P}_{2} \mathrm{O}_{5}$ \\
\hline
\end{tabular}

It is evident from Table 7 that the estimated ultimate requirement of different fertilizers in terms of equivalent urea, TSP and MP if the current cropping pattern and agriculture practice do not change dramatically particularly due to new scientific break-through will be $3.10,1.68$ and 1.38 million tons respectively.

\section{Production and Supply of Fertilizers}

The present consumption of nitrogen and $\mathrm{P}_{2} \mathrm{O}_{5}$ are met from local production and by some import while the consumption of $\mathrm{K}_{2} \mathrm{O}$ is met through import only as there are no facilities for producing potash fertilizers locally.

\subsection{Local production of Nitrogen Fertilizers}

Bangladesh Chemical Industries Corporation operates six urea fertilizers, one ammonium sulfate and two DAP plants. KAFCO, a joint-venture between the Government of Bangladesh and foreign companies produces urea fertilizer and extra ammonia product for export. The total installed capacity of seven plants for urea fertilizer is $2,895,700 \mathrm{t}$ per year and that for ammonia $1,886,700 \mathrm{t}$ per year. The lone ammonium sulfate plant has installed capacity of $10,000 \mathrm{t}$ ammonium sulfate per year. The two DAP plants based on local ammonia and imported Phosphoric Acid has installed capacity of 489,600 t DAP per year equivalent to 191,144 t urea. Table 9 provides some information on these plants.

Table 9: Information on Nitrogen Fertilizer Production Facilities $[1,6$

\begin{tabular}{lll}
$\begin{array}{l}\text { Name of the } \\
\text { Plant and location }\end{array}$ & $\begin{array}{l}\text { Year of establishment } \\
\text { and commercial production }\end{array}$ & $\begin{array}{l}\text { installed capacity } \\
\text { tpd (tpy) }\end{array}$ \\
\hline $\begin{array}{l}\text { UREA } \\
\text { NGFF (Fenchugonj) }\end{array}$ & $\begin{array}{l}1960 \text { (December, 1962) } \\
\text { UFFL (Ghorasal) }\end{array}$ & $\begin{array}{l}\text { urea: } 339(106,000) \\
\text { urea: } 1442(470,000)\end{array}$ \\
$\begin{array}{l}\text { ZFCL (Ashugonj) } \\
\text { PUFF (Polash) }\end{array}$ & $\begin{array}{l}1981 \text { (July, 1983) } \\
\text { urea: } 1600(528,000)\end{array}$ \\
$\begin{array}{l}\text { CUFL (Rang, 1986) } \\
\text { JFCL (Tarakandi) }\end{array}$ & 1987 (October, 1987) & $\begin{array}{l}\text { urea: } 305(95,000) \\
\text { urea: } 1700(561,000)\end{array}$ \\
KAFCO (Rangadia) & 1991 (July 1992) & urea: $1700(561,000)$ \\
Ammonium Sulfate & 1995 (December, 1996) & urea: $1728(575,425)$ \\
NGFF (Fenchugonj) & 1969 (1969) & AS: $33(10,000)$ \\
& & Eqv, urea: $(4,566)$ \\
DAP & & DAP: $800(240,000)$ \\
DAP-1 (Rangadia) & 2006 (March, 2007) & Eqv. urea $(93,000)$ \\
DAP-2 (Rangadia) & 2008 & DAP: $800(249,600)$ \\
& & Eqv. urea $(97,544)$ \\
\hline
\end{tabular}

The total installed capacity of urea including equivalent urea is $309,1819 \mathrm{t}$ per year. The production of urea fertilizers including equivalent urea fertilizers are listed in Table 10 for 2001-02 to 2006-07.

Table 10: Production Import and Consumption of Urea Fertilizers (during the period 2001-07, in thousand tons)

\begin{tabular}{lllllll}
\hline Year & $\begin{array}{l}\text { BCIC } \\
\text { Production }\end{array}$ & $\begin{array}{l}\text { KAFCO } \\
\text { Production }\end{array}$ & \multicolumn{3}{c}{ Import from } & \multirow{2}{*}{$\begin{array}{l}\text { Actual } \\
\text { sales }\end{array}$} \\
\cline { 4 - 6 } & & & KAFCO & Overseas & Total & \\
\hline $2001-02$ & 1545.7 & 609.0 & 260.0 & 260.8 & 520.8 & 2251.9 \\
$2002-03$ & 1950.0 & 611.4 & 262.5 & 23.2 & 285.7 & 2239.2 \\
$2003-04$ & 1986.2 & 569.3 & 235.0 & - & 235.0 & 2323.5 \\
$2004-05$ & 1878.3 & 685.2 & 315.0 & 252.3 & 567.4 & 2523.1 \\
$2005-06$ & 1730.4 & 573.8 & 313.2 & 323.3 & 636.7 & 2451.4 \\
$2006-07$ & 1819.0 & 661.4 & 350.0 & 399.0 & 749.0 & 2568.0 \\
\hline
\end{tabular}


During the same period, there was no local production of DAP and all the DAP consumed were imported from overseas. For the years 2004-05, 2005-06 and 2006-07, the consumptions of DAP were 171,000, 130,000 and $115,000 \mathrm{t}$ respectively while those for NPKS were 90,000, 110,000 and 72,000 t respectively. Table 11 provides data on consumption of urea, DAP and NPKS for 2004-05 through 2006-07.

Table 11: Consumption of Urea, DAP and NPKS for 2004-2007[1, 4]

\begin{tabular}{lllll}
\hline Year & Urea $(\mathrm{t})$ & $\mathrm{DAP}(\mathrm{t})$ & $\mathrm{NPKS} * *(\mathrm{t})$ & Equivalent $(\mathrm{t})$ \\
\hline
\end{tabular}
\begin{tabular}{rrrrr} 
Yrea $(t)$ & DAP $(t)$ & NPKS** $(t)$ & Equivalent $(t)$ \\
\hline $2004-05$ & $2,523,113$ & $171,000\left(66690^{*}\right)$ & $90,000\left(9782^{*}\right)$ & $2599,585^{*}$
\end{tabular}

$\begin{array}{lllll}2005-06 & 2,454,375 & 130,000(50,700 *) & 110,000\left(11956^{*}\right) & 2514,031^{*}\end{array}$

$\begin{array}{lllll}2006-07 & 2,568,044 & 115,000(44,850 *) & 72,000\left(7826^{*}\right) & 2620,720 *\end{array}$

** NPKS: 5:10:15; * equivalent urea

The present production by BCIC's six urea plants has been at about $78 \%$ of the rated capacity about 1800,000 t per year. Though BCIC owns $47 \%$ share of $\mathrm{KAFCO}$, it is required to buy urea from $\mathrm{KAFCO}$ at the prevailing international market price. In view of the ageing of the plants and larger natural gas requirement per unit urea against the plants built now $\left(700 \mathrm{~m}^{3} \mathrm{NG} / \mathrm{t}\right.$ urea), these plants, namely, NGFF (commissioned in 1961, $1670 \mathrm{~m}^{3} \mathrm{NG} / \mathrm{t}$ urea) and PUFF (commissioned in $1986,1410 \mathrm{~m}^{3} \mathrm{NG} / \mathrm{t}$ urea) and UFFL (commissioned in $1970,1000 \mathrm{~m}^{3} \mathrm{NG} / \mathrm{t}$ urea) are to be shutdown sometime in near future and two large urea complex of the size of JFCL/ CUFL (each having yearly urea production capacity $561,000 / \mathrm{t}$ ) can be operated with about the same connected load of natural gas (the connected load for three old plants $2.29 \mathrm{MMmm}^{3} /$ day and that for two modern plants $2.44 \mathrm{MMm}^{3} /$ day) $[1,6]$. This would mean BCIC's installed capacity $2772,000 \mathrm{t}$ per year. With BCIC's share of KAFCO (47\%), the country will get annual supply of urea about $3042,349 \mathrm{t}$ which is close to the ultimate demand of urea fertilizer.

\subsection{Local Production of Phosphatic Fertilizers}

BCIC produces phosphatic fertilizers through TSP, SSP and DAP. A plant for producing SSP has been built in the private sector. Table 12 provides some information on production facilities of phosphatic fertilizer.

Table 12 reveals that the installed capacity of TSP equivalent is $697,000 \mathrm{t}$ per year. SSP plant of Hussain Chemicals Ltd. is not yet operational. DAP-1 is not operating at full capacity for non-availability of Phosphoric Acid, one of the two raw materials for DAP, while DAP-2 is not yet fully operational due to technical problems. The production of TSP and SSP by TSP complex is listed in Table 13 for 2004-05 through 2006-07.

The difference between production by TSP Complex and consumption of TSP are met through import. All the DAP's consumed were imported previously.
Table 12: Phosphatic Fertilizer Facilities in Bangladesh [7]

\begin{tabular}{|c|c|c|c|c|c|}
\hline \multirow[t]{2}{*}{$\begin{array}{l}\text { Plant and } \\
\text { Location }\end{array}$} & \multirow[t]{2}{*}{$\begin{array}{l}\text { Year: establishment and } \\
\text { (commercial production) }\end{array}$} & \multirow{2}{*}{\multicolumn{2}{|c|}{$\begin{array}{l}\text { Installed Product } \\
\text { capacity } \\
10^{3} \text { tpy }\end{array}$}} & \multicolumn{2}{|c|}{$\begin{array}{c}\text { Equivalent } \\
10^{3} \text { tpy }\end{array}$} \\
\hline & & & & TSP & Urea \\
\hline \multicolumn{6}{|l|}{ Under BCIC: } \\
\hline TSP Complex & 1970(1973) & 120 & TSP & 120 & - \\
\hline Chittagong & & 100 & SSP & 35 & - \\
\hline DAP-1 & $2006(2007)$ & 240 & DAP & 240 & 93.6 \\
\hline \multicolumn{6}{|l|}{ Rangadia } \\
\hline $\begin{array}{l}\text { DAP-2 } \\
\text { Rangadia }\end{array}$ & $\begin{array}{l}2008 \\
\text { not operati }\end{array}$ & 249.6 & DAP & \multicolumn{2}{|c|}{249.697 .5} \\
\hline \multicolumn{6}{|c|}{ Private Entrepreneur: } \\
\hline Hussain Chemi & s 2005 & 150 & SSP & 52.5 & - \\
\hline Fatulla & not operational yet & & & & \\
\hline Total $=$ & & & & & 191. \\
\hline
\end{tabular}

Table 13: Production and Consumption of Phosphatic Fertilizers

\begin{tabular}{lrc}
\multicolumn{3}{l}{ Table 13: Production and Consumption of Phosphatic Fertilizers } \\
\hline TSP (by TSP Complex) & Production & Total Consumption \\
\hline $2004-05$ & & \\
$2005-06$ & 53848 & 420000 \\
$2006-07$ & 56392 & 436000 \\
\hline SSP (by TSP Complex) & 50430 & 340000 \\
\hline $2004-05$ & & \\
$2005-06$ & 162531 & 171000 \\
$2006-07$ & 135137 & 122000 \\
\hline DAP(DAP-1 and DAP-2) & 117641 & \\
\hline $2004-05$ & & 171000 \\
$2005-06$ & - & 1150000 \\
$2006-07$ & - & \\
\hline
\end{tabular}

If the installed capacities of TSP complex, DAP plants and SSP plant of Hussain Chemicals Ltd. could be fully utilized the net local yearly production of TSP equivalent will be close to 700,000 t. The sector is failing because of non-availability of elemental sulfur, phosphate rock and phosphoric acid. Placement of fund timely and procurement procedure have aggravated the situation. Nevertheless, besides solving the existing problems of this sector; the country should aim at achieving TSP equivalent production capacity close to 1 million ton. Additional TSP equivalent of 300,000 t can be met by producing SSP for its ability to supply sulfur also needed in some areas in the country.

\subsection{Local Production of Muriate of Potash}

Though the application of Potash is vital for plant for its many beneficial functions, this is not being used in Bangladesh in the required ratio with respect to $\mathrm{Ni}$ trogen fertilizer. There is no facility in the country to produce Potash fertilizer. This fertilizer is basically a mined product requiring little or no beneficiation. The beneficiation involves crushing, screening, compaction/granulation. The mining companies actually perform these operations, and market the desired potash fertilizer world wide.

From the view point of Bangladesh, there is now no urgency to build potash ore beneficiation plant. It should rather import potash fertilizer in bulk and bag it at the port side covered storage areas. It should plan to build bulk storage area having capacity to store at least 100,000 $\mathrm{t}$ potash fertilizer including bagging fa- 
cility so that at least $700,000 \mathrm{t}$ of potash fertilizer can be handled annually and this is about $50 \%$ the recommended use.

\section{Strategy for Developing the Fertilizer Sector}

Based on the recent studies and what has been discussed here above, there is a need to develop the sector by building new urea, SSP, Phosphoric Acid and Sulfuric Acid plants for assuring supply of different fertilizers (N,P and $\mathrm{K}$ nutrients) timely. Table 14 shows the plants needed to be planned and built without loss of time; and Table 15 provides some data on possible plant location, type of plant, total investment and implementation time.

Expected total capital investment would be around US\$ 1860 million of which foreign currency portion is about US\$ 1442 million including physical contingency, price escalation and working capital.

BCIC has already selected two sites for urea plants, one at NGFF site (the project is called Sylhet Fertilizer Co. Ltd (SFCL)) and another at Sirajgonj (the project is called North West Fertilizer Co. Ltd (NWFCL)) having identical capacity mentioned in Table 14 [1]. It has already been proposed that Phosphoric Acid facility would be built close to DAP-1 and DAP-2 [4]. The sites for SSP and Muriate of Potash Handling Facility have been proposed considering access to sea-ports and regional industrialization.

BCIC has the proven experience of building, operating and maintaining such grass-roots complexes and facilities for the urea fertilizer. BCIC have utilized the following process technologies [1, 6, 8, 9]:

$$
\begin{aligned}
& \text { Ammonia Process } \quad \text { CCC (USA); ICI and Kellogg; Uhde; Chi- } \\
& \text { nese; Kellog and Haldor Topsoe } \\
& \text { Urea Process CCC (USA); TEC-MTC C-process, D- } \\
& \text { process and ACES process; Stamicarbon, } \\
& \text { Chinese and Snamprogetti } \\
& \text { CO2-Removal } \quad \text { CCC(USA); Vetrocoke; Benfield and UOP } \\
& \text { Urea Product Prilling: Shower and Spinning Bucket } \\
& \text { Granular: Norsk-Hydro; Hydro Agri (The }
\end{aligned}
$$

Monsanto contact process has been used for the production of sulfuric acid. For phosphoric acid, the process of Hitachi Zosen has been used. For TSP and SSP, Hitachi Zosen has provided the technology.

There are a number of process licensors who can provide proven processes. BCIC should select processes which are well proven with respect plant size, raw materials, product quality and equipment/machinery and operability.

\subsection{Implementation of the Projects}

BCIC has the experience of implementing similar grass-roots projects by contracting arrangements such LSTK (Lump Sum Turnkey) and Cost plus Fee. BCIC can use either of the arrangements but LSTK arrangement would be more efficient considering the existing
PPR-2008. The scope of work and supply for the General Contactor and the Client are listed below, Table 16, for building these plants and facilities under LSTK contracting arrangement $[1,7]$. Prior to appointment of the General Contractor the following works can be carried out to save time which will lead to reduction of implementation period by about 4-10 months depending upon the nature of the project.

- Completing Paper Works for the Creation of the Envisaged Enterprise

- Arranging funds for financing the project

- Acquisition of Land for the Plant Site and Jetty

- Making Arrangement for Site Filling and Land Preparation

- Initiating steps for obtaining Environmental Clearance Certificate from DOE

- Preparation of IEE and EIA reports for the complex

- Preparation of Technical Specification

- Preparation of Contract Document

- Preparation of Pre-qualification applications for short-listing potential General Contractors

- International Advertisement and distribution of Pre-qualification Applications

- Receiving the Pre-qualification Applications from the potential General Contractors

- Distribution of the Bid Documents amongst the Pre-qualified Potential General Contractors

- Receiving the Bids

- Evaluation of the Bids and Selection of the General Contractor

- Evaluation of Pre-qualification Applications and short listing qualified potential General Contractors

- Preparation of Bid Documents for the Selection of General Contractors

- Issue of Letter of Intent to the Selected Contractor

- Contract Negotiation

- Signing of the Contract with the General Contractor

- Opening of Letter of Credit in favour of the General Contractor

- Making Arrangement for the Construction of Jetty

- Arranging Assent for Right of Way for the Construction of roads, pipeline etc.

- Arranging Temporary Supply of utilities at the Plant Site for the Project Personnel

- Arranging Office Accommodation with Computers, Internet, Fax, Telephone at the Site

\subsection{Project Financing}

There are several options for financing these projects as mentioned below: 


\begin{tabular}{|c|c|c|c|c|}
\hline Plant & No. of plants & $\begin{array}{l}\text { Capacity of each plant, tpd } \\
\text { (tpy) }\end{array}$ & Basic raw materials & Type of plant \\
\hline Urea & 2 & $1700(561,000)$ & Natural Gas & $\begin{array}{l}\text { grass-roots } \\
\text { ammonia-urea complex }\end{array}$ \\
\hline $\begin{array}{l}\text { SSP (consisting of SSP plants } \\
\text { and Sulfuric Acid Plant) }\end{array}$ & 4 & $800(240,000)$ & $\begin{array}{l}\text { Imported phosphate rock }\left(32 \% \mathrm{P}_{2} \mathrm{O}_{5}\right) \\
\text { and sulfuric acid produced on site. }\end{array}$ & grass-roots complex \\
\hline Sulfuric Acid & 1 & $1200(360,000), 96 \% \mathrm{H}_{2} \mathrm{SO}_{4}$ & Imported sulfur & grass-roots complex \\
\hline $\begin{array}{l}\text { Phosphoric Acid (consisting } \\
\text { of PA plant and Sulfuric Acid } \\
\text { plant for DAP-1 and DAP-2) }\end{array}$ & 1 & $740(226,440) 100 \%$ P2O5 & $\begin{array}{l}\text { Imported phosphate rock }\left(32 \% \mathrm{P}_{2} \mathrm{O}_{5}\right) \\
\text { and Sulfuric Acid produced on site }\end{array}$ & grass-roots complex \\
\hline Sulfuric Acid & 1 & $2132(652,392), 100 \% \mathrm{H}_{2} \mathrm{SO}_{4}$ & Imported sulfur & grass-roots complex \\
\hline $\begin{array}{l}\text { Muriate of Potash Handling, } \\
\text { Bagging and Storage Facility }\end{array}$ & 1 & $\begin{array}{l}\text { Bulk Storage: } 100,000 \mathrm{t} \\
\text { Bagged Storage: } 15,000 \mathrm{t} \\
\text { Unloading rate: } 4,000 \mathrm{tpd} \\
\text { Bagging rate: } 2000 \mathrm{tpd}\end{array}$ & Imported fertilizer grade MP & grass-roots complex \\
\hline
\end{tabular}

\begin{tabular}{|c|c|c|c|c|}
\hline Plant and Capacity & Type of plant & Location & $\begin{array}{l}\text { Total Investment } \\
\text { (FC portion) } \\
\text { million US \$ }\end{array}$ & $\begin{array}{l}\text { Implementation } \\
\text { period, (months) }\end{array}$ \\
\hline Urea-1 : 1700 tpd & $\begin{array}{l}\text { grass-roots } \\
\text { ammonia-urea } \\
\text { complex }\end{array}$ & NGFF Site & $700(560)$ & 48 \\
\hline Urea-2: 1700 tpd & $\begin{array}{l}\text { grass-roots } \\
\text { ammonia-urea } \\
\text { complex }\end{array}$ & Sirajgonj & $700(560)$ & 48 \\
\hline $\begin{array}{l}\text { SSP } 1-4: 800 \text { tpd } \times 4=3200 \text { tpd } \\
\text { Sulfuric Acid : } 1200 \text { tpd }(96 \% \\
\text { H2SO4; for SSP 1-4) }\end{array}$ & $\begin{array}{l}\text { grass-roots complex } \\
\text { grass-roots }\end{array}$ & $\begin{array}{l}\text { Mongla port (close to the port area) } \\
\text { in the same area of SSP }\end{array}$ & $\begin{array}{l}30 \times 4=120(85) \\
65(45)\end{array}$ & 30 \\
\hline $\begin{array}{l}\text { Phosphoric Acid : } 740 \text { tpd }(100 \% \\
\text { P2O5; for DAP-1 and 2) }\end{array}$ & grass-roots complex & Close to DAP-1 and DAP-2 Rangadia & $150(105)$ & 48 \\
\hline $\begin{array}{l}\text { Sulfuric Acid : } 2132 \text { tpd }(100 \% \\
\text { H2SO4; for PA) }\end{array}$ & grass-roots complex & in the same area of PA & $100(69)$ & \\
\hline $\begin{array}{l}\text { Muriate of Potash Handling Facility } \\
\text { Bulk storage: } 100,000 \mathrm{t} \\
\text { Bagging rate: } 2000 \mathrm{tpd} \\
\text { Bagged area: } 15000 \mathrm{t} \\
\text { Unloading rate: } 4000 \mathrm{tpd}\end{array}$ & grass-roots & TSP complex site & $25(18)$ & 24 \\
\hline
\end{tabular}

a) The entire capital can be borrowed from the commercial banks operating in Bangladesh at the interest rate below the calculated financial IRR for long term investment. BCIC will provide the guarantee.

b) BCIC will provide the local currency requirement from its own source while the foreign currency portion will be borrowed from the commercial banks operating in Bangladesh at the interest rate below the calculated financial IRR for long term investment. BCIC will provide the guarantee for the bank loan. BCIC's contribution in local currency will make the equity.

c) The Government of Bangladesh can arrange the entire investment by treating these as special projects by availing donor's loan for foreign currency portion while the local currency portion comes as a loan to the project from the Government. The interest rate is to be below the calculated financial IRR.

d) The project can be financed with Suppliers Credit for the foreign currency portion while BCIC provides the local currency portion of investment as equity. In this case, the General Contractor arranges the fund and the Government stands as a guarantee for the credit.

e) The Government can go for bilateral loan arrange- ment for each project separately to sources like OECF (Japan), SFD (Saudi Fund for Development) etc. for the foreign currency portion of the investment while the Government provides the local currency portion. In such case, the procurement procedure of the funding agencies will have to be used to utilize the fund.

f) The Government can create a special fund out of the foreign remittances sent by wage earners over a period of five years as per the disbursement schedule of the projects. Creating a fund of US\$ 1400 million over five years against the yearly remittance of US $\$ 8$ billion should not have any adverse effect on the country's foreign reserve.

The interest for the long-term loan whether for local currency portion or foreign currency portion shall be below the calculated IRR (financial) whatever may be the funding source.

It is desirable that the repayment of loan and interest incurred shall be made on annual basis as per the loan agreement as soon as the facility becomes operational over the economic life span in respective currencies. One-year grace period for the repayment of principal amount is desirable if the repayment of the principal and interest therefor commences from the first year of operation. Experiences show that the supplier's credit 


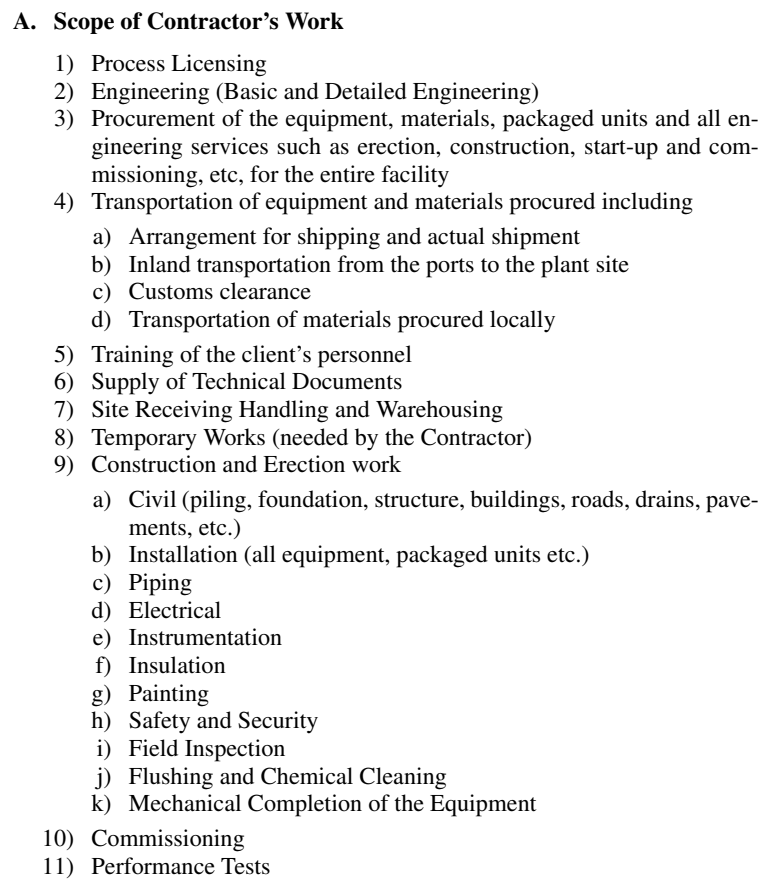

\section{B. Scope of the Client's Work}

1) Review and Approval of all Engineering Documents Produced by the Process Licensors, Contractor and Vendors

2) Obtaining Permits and Import License

3) Assistance to Contractor for Customs Clearance

4) Test Operation and Performance under the Direct Supervision of the Contractor

C. Scope of the Contractor's Supply

1) All Itemized Equipment and Packaged Units

2) Piping Materials Including Accessories

3) Instrument Equipment and Materials

4) Electrical Equipment and Materials

5) Steel Structures and Pipe Racks

6) Insulation and Painting Materials

7) Bulk Materials (Pipes, fittings, valves, steam traps, cables, switches etc.)

8) Spare Parts as Agreed plus any other things

D. Scope of the Client's Supply

1) Handing Over the Plant Site to the Contractor in Conditions as Agreed

2) Equipment and Materials Itemized

3) Raw Materials, Utilities, etc. Itemized

4) Bonded Area for Speedy Delivery of Equipment and Materials from the Port terms ask for repayment of the principal and interest in 10 years from the year of operation with one-year grace period for the principal installment.

The ownership of these projects must lie with BCIC because of interdependence, profitability issues, pricing plus subsidy to the farmers. Conventional criteria such as IRR, ERR, Cost Benefit Ratio etc. cannot reflect the benefit of these projects in quantifiable terms in the context of country's food security and social entitlements.

\subsection{Natural Gas Supply for Urea Plants}

The two urea plants when commissioned would not require additional gas if NGFF, UFFL and PUFF are shut down. Whether these are shutdown or not, BCIC should develop 4 natural gas production wells each capable of producing 25 MMSCFD. Two such wells can be developed in each of these fields namely, Fenchugonj and Habigonj. The gas from the wells of Fenchugonj shall be piped independently to the urea plant at NGFF site, while the gas produced from the Habigonj field shall be swapped for the gas to be used by the urea plant at Sirajgonj. This will, however, require BCIC an additional investment of US\$ 40 million including well development, gas processing plant and dedicated transmission line as required. The investment will be recovered from the gas to be used in producing urea. This will rather improve Petrobangla's gas supply.

\subsection{Supply of Elemental Sulfur, Phosphate Rock and Muriate of Potash}

The Government of Bangladesh can ensure regular and stable supply of elemental sulfur, phosphate rock and muriate of potash fertilizer through long term agreement with the mining companies. These agreements must be for at least 30 years. This would require the Government to prove that it is a worthy party for long term relationship.

\subsection{Why Should Bangladesh Produce Fertilizers?}

The international markets for different fertilizers such as urea, TSP, DAP and MP were very volatile during the past four years. It was the sellers market for TSP, DAP, MP and Phosphoric Acid because of the cartel controlling mining operations and fertilizer productions. The prices of different fertilizers in the international market in December, 2008 are listed in Table 17.

Based on December, 2008 international price, the cost different fertilizers to be produced/imported and used as discussed above would be US \$ 1.307 billion as shown in Table 18.

If the different projects envisaged above are not implemented, the farmers will not use balanced fertilizers, the yield will suffer and there will be drainage of foreign reserve for importing staple cereals, other food items and fertilizers. This would mean additional expenses in FE in excess of US\$ 1.70 billion 
Table 17: Fertilizer Prices in the International Market (December 2008)

\begin{tabular}{|c|c|c|c|}
\hline Product & $\begin{array}{l}\text { Price FOB } \\
\text { US } \$ / t\end{array}$ & Remarks & $\begin{array}{l}\text { Production Cost } \\
\text { US } \$ / t\end{array}$ \\
\hline Urea & $250-265$ & Arab Gulf & $\begin{array}{l}\sim 100 \text { (BCIC plant avg.) } \\
\sim 160 \text { (KAFCO) }\end{array}$ \\
\hline DAP & $450-500$ & Morocco & $1357^{*}(\mathrm{BCIC})$ \\
\hline TSP & $350-400$ & North Africa & $757 *(\mathrm{BCIC})$ \\
\hline MP & $\begin{array}{l}580-950 \\
590-640 \\
525-980\end{array}$ & $\begin{array}{l}\text { Jordan } \\
\text { China } \\
\text { Canada }\end{array}$ & $\ldots .$. \\
\hline $\begin{array}{l}\text { Phosphoric Acid } \\
\text { (100\% P2O5) }\end{array}$ & $\begin{array}{l}1600-2000 \\
1200-1600\end{array}$ & $\begin{array}{l}\text { Morocco/Jordan } \\
\text { cash spot }\end{array}$ & $\ldots \ldots$ \\
\hline
\end{tabular}

Table 18: Cost of Fertilized to be Produced/Imported

\begin{tabular}{crrr}
\hline Product & Price & Qty, t & $\begin{array}{r}\text { Total value } \\
\text { in million US\$ }\end{array}$ \\
\hline Urea $\$ / \mathrm{t}$ & & 600 \\
DAP & 200 & $3,000,000$ & 150 \\
TSP & 450 & 400,000 & 42 \\
SSP & 350 & 120,000 & 125 \\
MP & 125 & $1,000,000$ & 360 \\
\hline Total & 600 & 600,000 & 1307 \\
\hline
\end{tabular}

every year. These projects will contribute to the country's economic growth as well as expansion of chemical industries that employ state-of-the-art technology. This will make the agriculture in the country sustainable and make it less dependent on import of fertilizers such as urea, phosphatic ones and muriate of potash.

\section{References}

[1] Feasibility Study Report for Setting Up Two New Urea Fertilizer Factories in Bangladesh, Technical report, Ministry of Industries, GOB, 2008

[2] ADB, Appraisal of the Chittagong Urea Fertilizer Project

[3] Bangladesh Economic Review, Finance Division, Ministry of Finance, GOB, 2007

[4] BBS, Statistical Year Book of Bangladesh, Bangladesh Bureau of Statistics, 2006

[5] UNIDO, Fertilizer Manual, Kluwer Academic Publishers, 3rd edition, 1998

[6] Quader AKMA, Natural gas and the fertilizer industry, Energy for Sustainable Development, 2003. 7(2):pp. 40 - 48. doi: DOI : $10.1016 /$ S0973-0826 (08)60353-1

[7] Techno-Economic Feasibility Study for the Setting up of A phosphoric Acid Manufacturing Facility for Two Under Construction DAP Factories, Technical report, Chemical Engineering Department, BUET, 2006

[8] Technical Audit Reports of Urea Fertilizer Plant of BCIC, Technical report, Bangladesh Chemical Industries Corporation, 2001

[9] Quader AKMA, Performance of Ammonia-Urea Industry in Bangladesh, in Proceedings of CHEMCON-2007, IICHE, Kolkata, India, 2007 